\title{
Livelihood Status of Fishing Community of Talma River in the Northern Part of Bangladesh
}

\author{
Md. Ataur Rahman ${ }^{1}$, Md. Nurunnabi Mondal ${ }^{1, *}$, Kazi Ahsan Habib², Jannatun Shahin", \\ Md. Golam Rabbane \\ ${ }^{1}$ Department of Fisheries Management, Bangabandhu Sheikh Mujibur Rahman Agricultural University, Gazipur, Bangladesh \\ ${ }^{2}$ Department of Fisheries, Sher-e-Bangla Agricultural University, Sher-e-Bangla Nagar, Dhaka, Bangladesh \\ ${ }^{3}$ Department of Fisheries, Ministry of Fisheries and Livestock, Matshya Bhaban, Ramna, Dhaka, Bangladesh \\ ${ }^{4}$ Department of Fisheries, University of Dhaka, Dhaka, Bangladesh
}

\section{Email address:}

ataurazim2207@gmail.com (Md. A. Rahman),nurunnabi@bsmrau.edu.bd (Md. N. Mondal), ahsan_sau@yahoo.com (K. A. Habib), shahinj.dof83@gmail.com (J. Shahin),rabbane_du@yahoo.com (Md. G. Rabbane)

\section{To cite this article:}

Md. Ataur Rahman, Md. NurunnabiMondal, Kazi Ahsan Habib, JannatunShahin, Md. GolamRabbane. Livelihood Status of Fishing Community of Talma River in the Northern Part of Bangladesh. American Journal of Life Sciences. Vol. 3, No. 5, 2015 , pp. $337-344$. doi: $10.11648 /$ j.ajls.20150305.11

\begin{abstract}
The study was conducted to investigate the socio-economic profiles of the fishermen of river Talma in Panchagarh district in the Northern part of Bangladesh. Pertinent information was collected from fifty randomly selected fishermen from the study area during the period of eight months from March to October, 2014. In the study area the fishermen age range from 20 to 66 years. It was found that most of the fishermen (58\%) illiterate though a small proportion completed primary level of education. Among them Muslims were $86 \%$ and Hindus $14 \%$. About $68 \%$ of the fishermen had tin shed with bamboo house, while $26 \%$ and $6 \%$ of them had tin shed with tin and straw house, respectively. Annual income of the fishermen ranged from 35001-55000 BDT and they had large family size (member above 7) constituted 36\%. Forty eight percent of the fishermen used their own tube-well, while $40 \%$ and $12 \%$ used government and neighbors' tube-well, respectively. About $80 \%$ of the fishermen used kacha toilets and 16\% semi pakka toilets and 6\% of the fishermen had no sanitary facilities. In the study area, $86 \%$ of the fishermen were far from power plants and the rest of them had (14\%) access to electricity. Majority (46\%) of the fishermen was landless, while 38\% had 1-20 decimal lands and 16\% had above 20 decimal lands and significant proportion of fishermen depend upon village doctors (64\%) for their health facilities. Seventy six percent of fishermen were engaged in fishing as their main occupation, $16 \%$ in agriculture and $8 \%$ in daily labor. The study revealed that the fishermen of Talma River were mostly illiterate, poor income, lack of training exposure and lack of awareness about their health facilities and sanitation. So, provide soft term loan and building people awareness have been suggested to improve the livelihood status of fishermen in Talma River.
\end{abstract}

Keyword: Livelihood, Fishermen, Marketing Channel, Talma River, Northern Bangladesh

\section{Introduction}

Bangladesh is called a riverine country due to the presence of a large number of rivers. This river, their tributaries and distributaries flow through the country constituting a water way of the total area about $22,155 \mathrm{~km}$ [1]. The rivers are offering immense scope and potentiality for augmenting fish production and socio-economic security of the people living around. This sector provides 1.78 million people's full-time and part-time employment facilities [2]. Its plays an important role in the national economy of Bangladesh through employment generation, poverty alleviation, supply of animal protein and foreign exchange earnings [3]. This sector also contributes about $60 \%$ of the national animal protein in-take and $19 \%$ percent of the total protein in-take in the average Bangladeshi diet [4]. For subsistence fishermen and their families, the fish they catch is often their only source of protein and essential minerals.

Fish and fisheries are indispensable part in the livelihoods of the people of Bangladesh and it is the part of our cultural heritage [5]. Livelihood is made up of the capabilities, activities, and assets (including both material and social 
resources) that contribute to a means of living [6]. According to Chambers and Conway [7] livelihood comprise the capabilities, the assets (natural, physical, human, financial and social), the activities and the accesses to these that together determine the living gained by the individual household. Livelihood status of fishermen mostly depend on fisheries resources. Fishing is the main source of income of the river adjacent fishermen household. But the fishermen cannot catch fish properly due to economic, social and technical constraints. Thus, the socio-economic conditions of the fishermen are not so good. They are not capable to earn sufficient amount of money to meet basic needs [3]. Fishermen community is deemed to be one of the most vulnerable communities in terms of their livelihood opportunities in Bangladesh [8]. In Bangladesh, fishermen are very important communities, they lives hand to mouth and considered as the poorest among the poor [9]. Most of the fishermen are deprived of many amenities. All the times they have to struggle to survive, so, livelihood status of fishing community is not satisfactory at all [10].

The Talma River system is one of the major river systems of Panchagarh district. It has great influence on fish biodiversity and socio-economic status of fishermen. Many families are directly involved in fishing and earning to maintain their livelihood by fishing throughout the year. For proper development of fishing community, it is essential to understand the baseline information to initiate proper developmental steps and improve the livelihood of fishermen. But, there is no sufficient information about livelihood of fishermen community in Northern part of Bangladesh. However, few studies on socio-economic conditions of fishermen were carried out by [10-13] but all these efforts lack specific information of livelihood. Though, there are few works has been done on the socio-economic condition of rivers dwelling fishermen in different region of Bangladesh [9-10]. But, there is no previous information on the socio- economic condition of Talma River in the Northern part of Bangladesh. So, the main purpose of this study is to examine the socio-economic conditions of the fishermen of Talma River in the Northern region of Bangladesh.

\section{Materials and Methods}

The methodology followed and the materials used for undertaking the present study described below:

\subsection{Selection of Study Site}

The study was carried out in a village named Talma under Panchagahr Sadar upazila in Panchagahr district. The village was situated on the bank of the river Talma. The primary criterion for the selection of the study area was a suitable geographical coverage for wider variety of fish biodiversity and good numbers of fishing community (fishermen) of Talma River lives. For this, information was collected from Upazila Fisheries Officer (UFO) of Panchagahr Sadar regarding the fish biodiversity and concentration of fishing activities in the Talma River and finally Talma village was selected for sample collection.

\subsection{Selection and Category of Fishermen as Sample}

In the study, total 50 fishermen were randomly selected from the villages surrounding the river. Both professional and subsistence fishermen living around the area of Talma River was selected for the study.

\subsection{Study Period}

Data were collected by the researcher himself through personal interview of the fishermen. The study was conducted for a period of 8 months from March, 2014 to October, 2014. The samples and data were collected monthly basis throughout the study period.

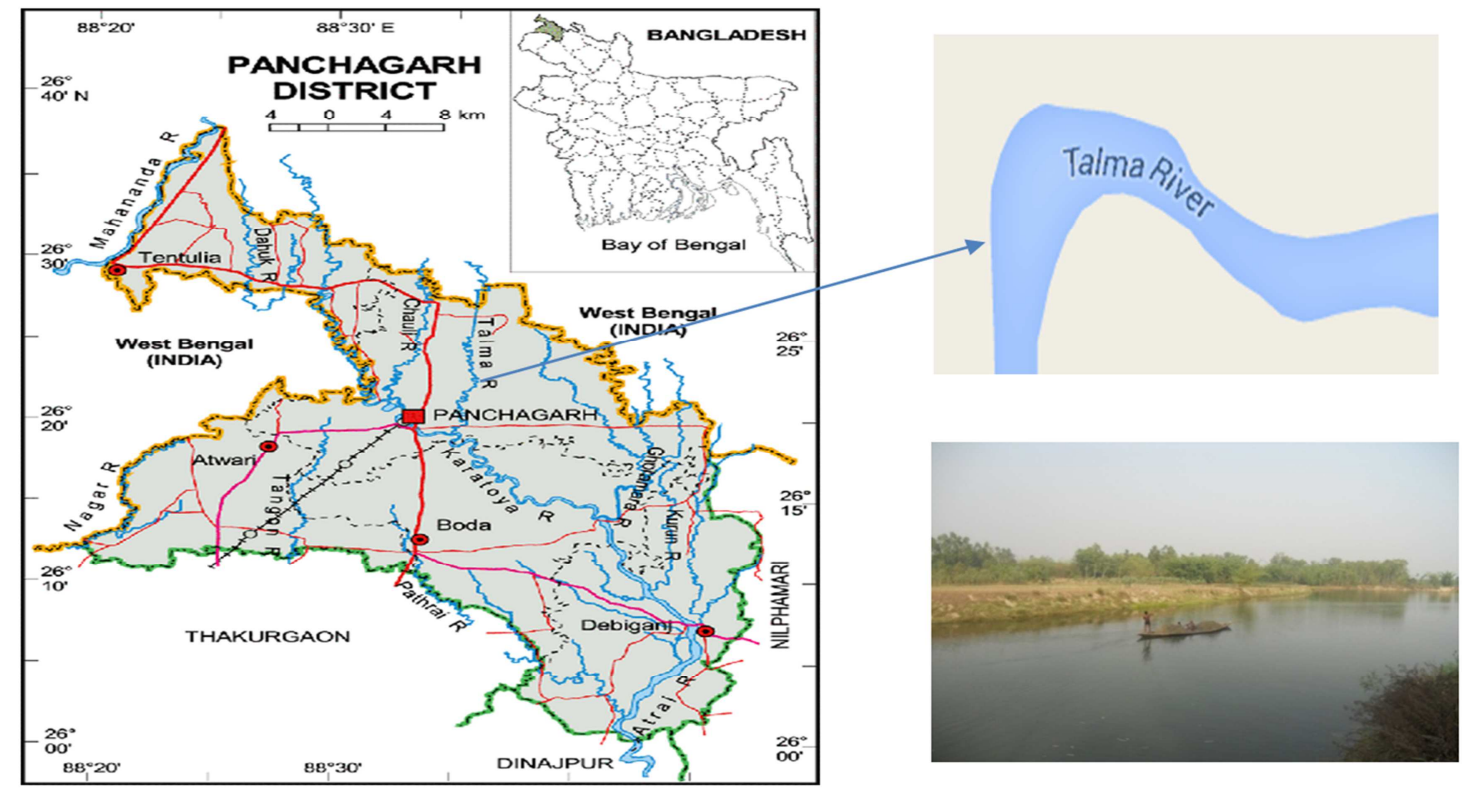

Figure 1. Map showing the Talma River in Panchagarh district. 


\subsection{Preparation of Interview Schedule}

Interview schedule is very important for collecting data by survey method. In order to get a complete picture of livelihood of fishermen and to fulfill the objectives of the study a draft interview schedule was prepared. The draft interview schedule was then used for pre-testing a few sample respondents. In pre-testing, attention was paid to incorporate any new information, which was not designed to asked and filled in the draft interview schedule. The interview schedule was then modified, changed and rearranged according to the experience gathered from pre-test. The final schedule was developed in logical sequence so that the fishermen could answer chronologically. The schedule included various questions related to socio-demographic condition, income of fishermen and family members, factors affecting the livelihood of the respondents and other relevant aspects of river fisheries.

\subsection{Data Collection}

During collection of data, both primary and secondary sources were considered. Primary data were collected from fishermen. Several visits were made to the study area to collect accurate information related to the objectives. For the study a combination of interview schedule, participatory rural appraisal (PRA) tool such as focus group discussion (FGD), social mapping and cross interviews with key informants were used for fishermen. Fishermen livelihood data were collected once per month.

\subsection{Data Processing, Analysis and Presentation}

The collected data were summarized and processed for analysis. These data were verified to eliminate all possible errors and inconsistencies. Tabular technique was applied for the analysis of data by using simple statistical tools like averages and percentages. Finally, the processed data were transferred to a master sheet from which classified tables were prepared revealing the finding of the study. For processing and analysis purpose, SPSS 16.5, MS Excel and MS word had been used. Tables and pie-charts had been used for data presentation.

\section{Result and Discussion}

\subsection{Age Structure and Religious Status}

The age of the fishermen ranged from 20 to 66 years with an average age of $39.68 \pm 12.44$ years. The fishermen were classified into the following four categories (Figure 2) according to their age.

Different categories of age groups such as young (20-30 years), middle age (31-40 years), old (41-50 years) and the oldest (above 50 years) were considered to examine the age structure. It appeared that young and middle age persons in the range of 20-40 years was the highest (58\%) and above 50 years was the lowest (20\%). [14] found that most fishermen
$(50 \%)$ belong to the age group of 31-40 years in the district of Mymensingh, Bangladesh. Similar results were also observed by [9] adjacent to the Old Brahmaputra River where people of $50 \%$ were ranged between $31-40$ years. [15] found age group of 35-40 years old was 30\% and the largest age class was 40-50 years old (56\%) at Birulia and Boroibari region, respectively in Turag river, Bangladesh.

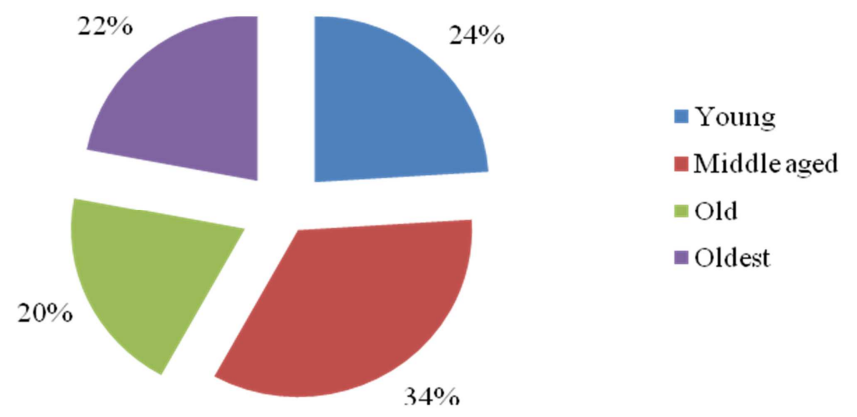

Figure 2. Distribution of fishermen according to their age.

Religion can play a very important role in the socio cultural activities of people. It was found that Muslims were featuring as the absolute majority (86\%) followed by Hindus (14\%) with no Buddhists or Christians. It was well known that only the lowest caste of the Hindu community engaged in this sector. [16] found in their study that most of the respondents were Muslim (83.33\%) and rest of them (16.67\%) were Hindu at Rajoir upazila of Madaripur district, Bangladesh. [10] noted in their study that Muslims were represented as absolute majority of fishermen in the study area (70\%) in Tista river, Rangpur. [17] and [6] found that all of the fishermen were belonging to the Hindu religion in Baluhar Baor, Jhenidah and Monirampur upazila, Jessore district in Bangladesh, respectively.

\subsection{Family Type and Family Size}

In rural Bangladesh, families were classified into two types: i) nuclear family; married couples with children, and ii) joint family; group of people related by blood and/or law. In this study, it found that $36 \%$ families were nuclear family and $64 \%$ was joint family (Figure 3 ). Family size is defined as the number of persons, either working or not, belonging to the same family. In the study, average family size of fishermen was found to $6.08 \pm 1.89$. Family size was categorized as small family (member 2 to 4), medium family (member 5 to 6 ) and large family (member above 7 ). During the period of the investigation, small family constituted $18 \%$, medium family constituted $46 \%$ and large family constituted $36 \%$ of the total surveyed fishermen (Figure 4). In this study the type of family found was small compared to other areas and communities of Bangladesh. About $42.5 \%$ of the fishermen living in nuclear family and the rest $(57.5 \%)$ in joint family were found in the district of Mymensingh by [14]. Joint families found in maximum region in Rangpur, Gazipur and Mymensingh district in Bangladesh, respectively by [9], [18] and [19]. [14] found 
that most of the fishermen (45\%) belonged to the medium family (member 4-5) in Mymensingh district. [20] found the highest percentages $(47.76 \%)$ of family had $7-8$ members, the lowest percentage (1.27\%) was obtained $1-2$ members of Marjat Baor at Kaligonj in Jhenidah district, Bangladesh. But Small family (member $<5$ ) was found in majority (48\%) in fishermen of the Baluhar Baor, Jhenidah, Bangladesh [17].

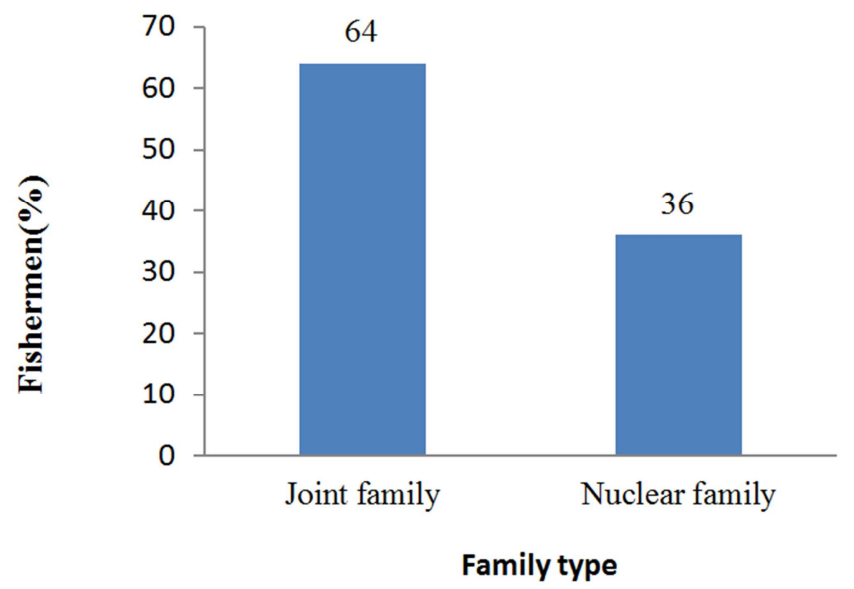

Figure 3. Distribution of fishermen according to family type.

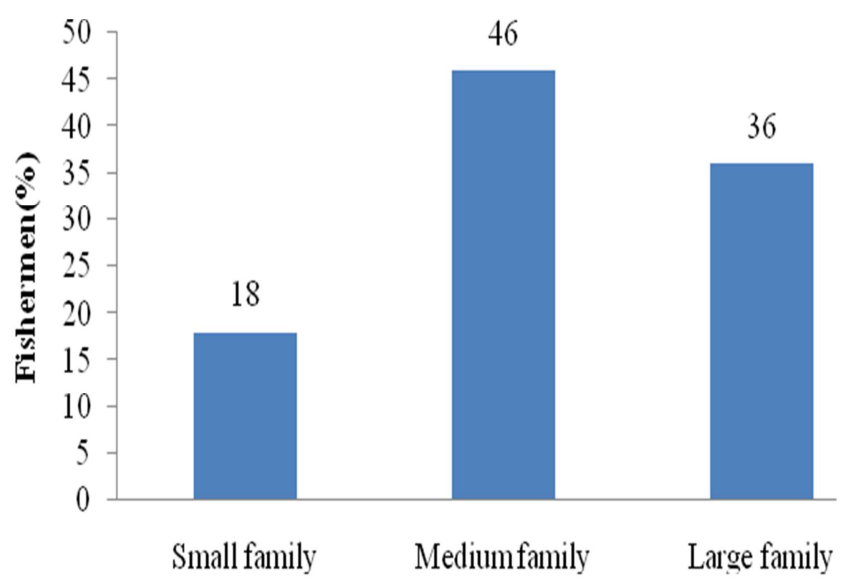

Figure 4. Distribution of fishermen according to their family size.

\subsection{Educational Status}

Education is the key determinant of the lifestyle and status in a society. The fishermen in the locality had varying level of educational background. Most of the fishermen were illiterate $(58 \%)$, small portion of them can sign only $(22 \%)$. Some had primary and secondary level of education (10\%) and $(8 \%)$, respectively but very few numbers of fishermen $(2 \%)$ had SSC level of education (Table 1). [20] found majority of fishermen $(60 \%)$ were illiterate in the Marjat Baor at Kaligonj in Jhenidah district. Similar results also mentioned by [11] and [6] while working with the fishermen of the Chalan Beel and Monirampur upazila, respectively. [16] also reported similar findings that $52.78 \%$ fish retailers had no formal education while working at Rajoir upazila of Madaripur district in Bangladesh.
Table 1. Distribution of the fishermen according to their educational status.

\begin{tabular}{lll}
\hline Categories & No. of fishermen $(\mathbf{n}=\mathbf{5 0})$ & \% of total fishermen \\
\hline Illiterate & 29 & 58 \\
Sign only & 11 & 22 \\
Primary & 5 & 10 \\
Secondary & 4 & 8 \\
SSC & 1 & 2 \\
Total & 50 & 100 \\
\hline
\end{tabular}

\subsection{Status of Physical Properties}

\subsubsection{Housing Condition}

Housing condition of the fishermen were categories as three main types: i) Tin shed with bamboo, only roof was tin, ii) Tin shed with tin, both roof and surroundings built by tin and iii) Straw, completely built by straw houses. Housing condition of the fishermen were dominated by Tin shed with bamboo (68\%), followed by Tin shed with tin $(26 \%)$ and Straw (6\%). No fisherman was found to have pakka house (Figure 5). [15] found 72\% and 32\% fishermen in Birulia and Boroibari had kacha house while 28\% and 68\% fishermen in Birulia and Boroibari had tin-shed house, respectively. [17] found housing condition was dominated by kacha (74\%) where [9] founded that majority of fishermen in Old Brahmaputra River (83\%) had kacha and 17\% had semi pakka housing facilities. [10] explored that the great majority (83\%) had kacha and 17\% had semi pakka house.

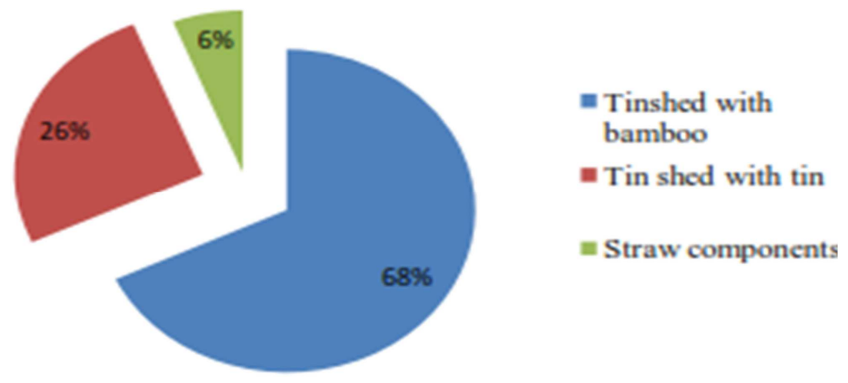

Figure 5. Distribution of fishermen according to housing condition.

\subsubsection{Drinking Water Facilities}

The provision of clean and safe drinking water is considered to the most valued elements in the society. The study showed that $100 \%$ of the fishermen households used tube-well water for drinking purposes and among them $48 \%$ fishermen used their own tube-well, 40\% used government tube-well and remaining $12 \%$ used neighbors tube-well as a source of water for drinking (Figure 6). [17] found in Baluhar Baor, Jhenidah district that household of $100 \%$ fishermen used tube-well water for drinking and among them, $96 \%$ household used owned tube-well, and remaining $4 \%$ used neighbors tube-wells. [20] showed that $82 \%$ fishermen used deep tube-well water while remaining $18 \%$ collected water from other sources such as river, canal water etc. in Marjat Baor at Kaligonj in Jhenidah district, Bangladesh. [9] found that $40 \%$ fishermen had their own tube-well, $50 \%$ used shared tube-well and remaining 10\% used neighbors tubewell. 


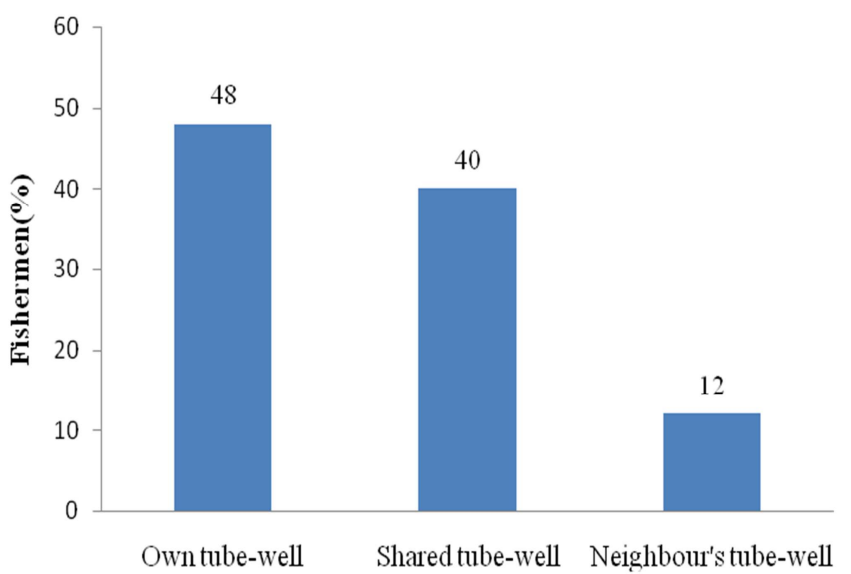

Figure 6. Distribution of fishermen according to drinking water sources.

\subsubsection{Sanitary Facilities}

It observed that sanitary conditions of the fishermen were very poor. Two types of toilets were used by fishermen: i) kacha- made of bamboo with leaf and inadequate drainage disposal and ii) semi pakka- made of brick with leaf or tin and inadequate drainage disposal. In the study, it revealed that $80 \%$ of the toilets were kacha, $16 \%$ toilets were semi pakka and $6 \%$ of the fishermen had no sanitary facilities (Figure 7). There was no pakka sanitation system used by the sampled fishermen. The present study revealed that the sanitary conditions of the fishermen were not satisfactory in the study area where [9] found in their study that $60 \%$ of the farmers had semi pakka, 30\% had kacha and 10\% had no sanitary facilities in the Old Brahmaputra River fishing community. [14] found that $62.5 \%$ of the farmers had semipakka, 25\% had kacha and $12.5 \%$ had no sanitary facilities in the Mymensingh district and [10] was also found similar result that $60 \%$ fishermen had kacha and $10 \%$ had semipakka toilet and $30 \%$ had no sanitary facility in the Tista River fishing community.

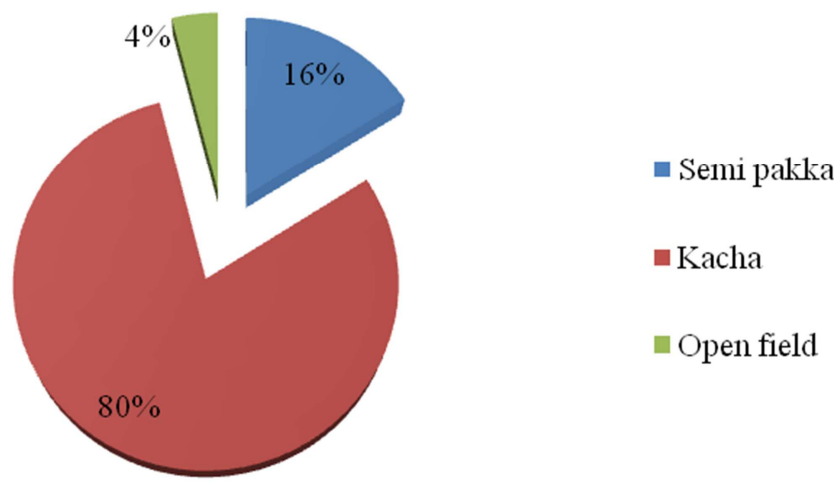

Figure 7. Distribution of fishermen according to the sources of sanitary facilities.

\subsubsection{Health Facilities}

Health service status was categorized into four groups: kabiraj, village quack doctor, upazila health complex and outdoor chamber of MBBS doctor. A significant proportion of fishermen depend upon village doctors (64\%) who actually posses no knowledge on medical science. About $22 \%$ respondent got health service from village kabiraj and 10\% from upazila health complex and only 4\% fishermen got health service from outdoor chamber of MBBS (Bachelor of Medicine and Bachelor of Surgery) doctors (Figure 8). [21] reported that health facilities of the fish farmer in the Shahrasti upazila, Bangladesh were poor and $70 \%$ of the fish farmers were dependent on village doctors, while $20 \%$ and $10 \%$ got health service from upazila health complex and MBBS doctors, respectively. [11] found that $84 \%$ of fishermen visit doctors whereas $2 \%$ of fishermen visit kobiraj and $14 \%$ of fishermen visit both doctors and kabiraj in Sirajgang district, Bangladesh. [14], [9] and [10] found that health facilities enjoyed by the fishermen were not satisfactory in their study. Generally fishermen took health suggestions from unskilled, non professional village quack doctor and kobiraj.

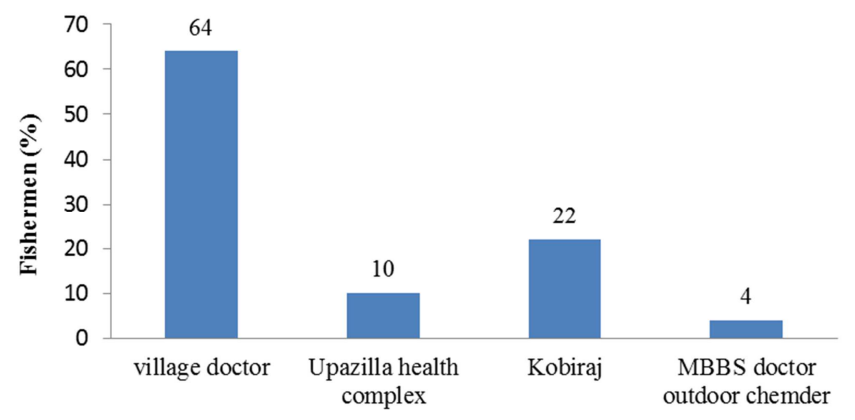

Figure 8. Distribution of fishermen according to the sources of health facilities.

\subsubsection{Electricity Facilities}

In the study area, $86 \%$ fishermen were far from power plants and the rest (14\%) had access to electricity, which was similar to the findings of [14], [9] and [10]. But [22] found no electric facility of the fishermen in the Nijhum Dwip Island, Hatiya upazila under Noakhali district, Bangladesh. From the study, it was found that there was lack of electricity facilities of most of the fishermen households.

\subsection{Financial Status}

\subsubsection{Land Properties}

Pattern of land tenure was one of the determinants of social and security situation and economic security [10]. Majority of the fishermen (46\%) had landless, while $38 \%$ of them had 1-20 decimal lands and only $16 \%$ had above 20 decimal lands. Usually the landless fishermen live in Government land (khas land) and they were unable to buy land due to very low income (Table 2). [6] found that $2 \%$ fishermen were landless and land owned by the fishermen was 0.02 to 1.57 ha in Monirampur upazila of Jessore district, Bangladesh. [22] found that average homestead area of fishermen were 8.75 decimal in Hatiya upazila under Noakhali district of Bangladesh. [16] found that $82 \%$ fishermen had less than 31decimal land including homestead in Rajoir upazila of Madaripur district, Bangladesh. 
Table 2. Land properties of fishermen in the surveyed areas.

\begin{tabular}{lll}
\hline Categories & No. of fishermen $(\mathbf{n}=\mathbf{5 0})$ & $\mathbf{\%}$ of total fishermen \\
\hline Landless & 23 & 46 \\
1-10 decimal & 11 & 22 \\
11-20 decimal & 8 & 16 \\
21-30 decimal & 4 & 8 \\
31-40 decimal & 3 & 6 \\
Above 40 decimal & 1 & 2 \\
Total & 50 & 100 \\
\hline
\end{tabular}

\subsubsection{Occupational Status}

Most of the fishermen in the study area were involved in fishing (main occupation). However, some were also engaged in agriculture and day labor. The study revealed that $76 \%$ of fishermen were engaged in fishing, $16 \%$ in agriculture and $8 \%$ in daily labor in sand business (Figure 9). [9] revealed that $70 \%$ of the fishermen were engaged in fishing as their main occupation, $20 \%$ in agriculture and $10 \%$ in daily labor in the Old Brahmaputra River fishing community under Mymensingh district, Bangladesh. [6] found in Monirampur upazila that major primary occupation of fishermen was fishing and that was found $90 \%$.

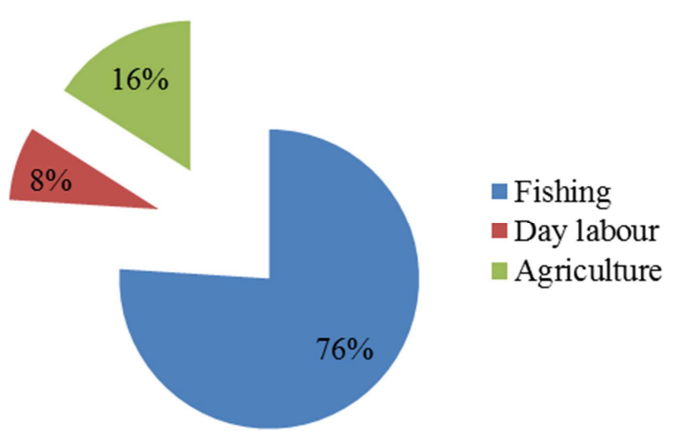

Figure 9. Distribution of fishermen according to their occupation.

\subsubsection{Annual Income of Fisherman}

Income is the most important factor for better understanding of the socio economic conditions of fishermen [11]. The fishermen were grouped into four categories based on their annual income and found that $24 \%$ fishermen annual income between 25000 to 35000 BDT (Bangladeshi Taka) and $64 \%$ fishermen income of 35001 to 55000 BDT and only $12 \%$ fishermen annual income above 55000 BDT (Table 3) which was more or less similar to the findings of [10] they found that about $63 \%$ of the fishermen had a moderate annual income and $37 \%$ had low incomes, however only $22 \%$ had high annual income in the fishing community of Tista River. [15] found that $63 \%$ fishermen in Birulia and $35 \%$ fishermen in Boroibari had a moderate annual income (30000-60000 BDT) in the Turag River fishing community. [9] revealed that about $60 \%$ of the fishermen had annual income between 24000 to 35000 BDT and $30 \%$ of the respondent had income in the ranged 35001 to 45000 BDT in the Old Brahmaputra River. [12] found 18600 to 27400 BDT annual income of the fisherman community of Dahia Beel under Natore district, Bangladesh.
Table 3. Annual incomes of the fishermen in the study areas.

\begin{tabular}{lll}
\hline Categories $($ BDT $)$ & No. of fishermen $(\mathbf{n}=\mathbf{5 0})$ & \% of fishermen \\
\hline $25000-35000$ & 12 & 24 \\
$35001-45000$ & 18 & 36 \\
$45001-55000$ & 14 & 28 \\
Above 55000 & 6 & 12 \\
Total & 50 & 100 \\
\hline
\end{tabular}

\subsubsection{Credit Access}

The national and local Non-Government Organization (NGO) like BRAC and Grameen bank provide credit only to the organized poor members for purchase of fishing gears and boats. About $32 \%$ of the fishermen did not need to borrow money but $22 \%$ borrow money from their neighbors, $10 \%$ from relatives, $20 \%$ took loan from NGO's and $16 \%$ from co-operatives for their fishing business. [9] found in the Old Brahmaputra River fishing community that $40 \%$ of fishermen were self sufficient and they did not need to financial help but 14\% borrow money from their neighbors, $18 \%$ from relatives, $22 \%$ took loan from NGO's and $6 \%$ from cooperatives for their fishing business which was similar to the present findings.

\subsection{Nets Used}

The fishermen in the Talma River used different types of nets locally called jhaki jal (cast net), boro jhaki jal (cast net), dharma jal (lift net), bishal jal, poiamari jal, ber jal (surrounding net), thela jal (push net), borshi (hook and line) etc.

\subsection{Market Structure and Marketing Channel}

Three types of fish marketing channel exist in the surveyed area. The status of fish marketing channel in the Talma River showed in the Diagram 1.

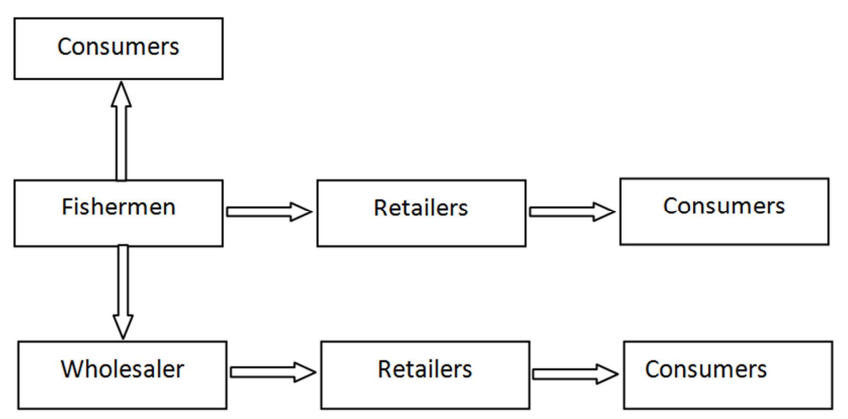

Diagram 1. Fish marketing channel in the Talma River.

\subsection{Problems in Fish Marketing}

Livelihoods of a large number of fishermen in the Talma River area were associated with catching fish, transportation and marketing systems. Usually the fishermen did not get good price by selling their fish due to interference of intermediaries, limited accessibility to the established market place and poor supply of ice. The fishermen want to establishment and reservation of a special fish corner in each market that help them to get good price for their harvested fish. For this purpose institutional support from local 
government authority is required.

\section{Conclusion}

The socio-economic condition of the fishermen in the adjacent area was not satisfactory. The education level of the fishermen was so poor and most of them were illiterate. Due to the lack of awareness as well as the poor income of the fishermen families, the education level of the fishermen children also very poor. Significant proportion of fishermen depends upon village doctors while most of the fishermen had no own land. At present, loss of biodiversity is an alarming in Talma River due to several reasons including degradation of natural habitats, excess exploitation using illegal fishing gears and techniques, use of toxins in agricultural land, lower level of water and construction of rubber dam. The Government should take some important stage to conserve fish biodiversity through excavating bed and dredging of bottom mud. Bank loan and other institutional credit should be made available on easy terms and condition to the fishermen. Government should take initiative to established educational institute, extended and development of transportation system and sanitary facilities, and to provide the preservation facilities in the study area. NGOs and other organization should come forwarded to supply net and other harvesting and marketing equipment to the fishermen with less fare that may reduce the harvesting and marketing cost. The fishermen should be trained up to build awareness, improve their livelihood status and fishing laws. A special "Fishers Corner" should be established in each market where the fisher can sell their fish directly to the consumers.

\section{Acknowledgement}

We express our gratitude to the Department of Fisheries Management, Bangabandhu Sheikh Mujibur Rahman Agricultural University, Gazipur, Bangladesh and Aquatic Bioresource Research Laboratory, Sher-e-Bangla Agricultural University, Dhaka, Bangladesh, for providing facilities. We also express our profound regards to the local fishermen of the River Talma for collecting data and to the UFO, Panchagar Sadar upazila, Panchagar district, Bangladesh, for his valuable suggestions and cooperation.

\section{Reference}

[1] M. J. Rahman, M. A. Wahab, and C. A. Meisner, "ECOFISHBD Project: A joint initiative of government-nongovernment-donor for hilsa and other fisheries resources conservation, productivity improvement and strengthening fishers capacity," National Fish Week 2015 compendium (In Bengali), Department of Fisheries, Ministry of Fisheries and Livestock, Bangladesh, 2015, pp.116-118.

[2] S. A. Azad, "Fisheries sector in socio-economic development of Bangladesh," National Fish Week 2015 compendium (In Bengali), Department of Fisheries, Ministry of Fisheries and
Livestock, Bangladesh, 2015, pp.13-23.

[3] M. J. Alam, "Socio-economic conditions of haor fishermen a field level study," BRAC university journal, vol. II (1), pp. 5763, 2005.

[4] DoF, "National Fish Week 2014 compendium (In Bengali), Department of Fisheries, Ministry of Fisheries and Livestock, Bangladesh, 2014,pp.144.

[5] M. H. Ali, M. D. Hossain, A. N. G. M. Hasan, and M. A. Bashar, "Assessment of the livelihood status of the fish farmers in some selected areas of Bagmara upazila under Rajshahi district," Journal of the Bangladesh Agricultural University, vol. 6(2), pp. 367-374, 2008.

[6] M. R. Islam, M. N. Hoque, S. M. Galib, and M. A. Rahman, "Livelihood of the fishermen in Monirampur upazila of Jessore district, Bangladesh,” Journal of Fisheries, vol. 1(1), pp. 37-41, 2013.

[7] R. Chambers and R. Conway, "Sustainable rural livelihood: practical concept for the 21 st century," Discussion paper, IDS No. 296, 1992.

[8] Z. Farhana and M. N. Naser, "Livelihoods of the two fishermen communities from Sirajganj and Chandpur districts of Bangladesh," Abstracts, 2nd Fisheries Conference and Research Fair, 2006, pp. 73-74.

[9] K. M. R. Kabir, R. K. Adhikary, M. B. Hossain, and M. H. Minar, "Livelihood status of fishermen of the old Brahmaputra River, Bangladesh," World Applied Sciences Journal vol. 16(6), pp. 869-873, 2013.

[10] M. A. R. Khan, M. I. Miah, M. B. Hossain, A. Begum, M. H. Minar, and R. Karim, "Fish biodiversity and livelihood status of fishing community of Tista River, Bangladesh," Global Veterinaria, vol. 10(4), pp. 417-423, 2013.

[11] M. F. A. Kostori, "Socio-economic condition of fishermen of the Chalan Beel under Tarash Thaha of Sirajganj in Bangladesh," Bangladesh Research Publications Journal, vol. 6(4), pp. 393-402, 2012.

[12] F. A. Flowra, M. B. Alam, M. A. Hossain, M. A. Samad, and S M. Galib, "Livelihood aspects of fishermen community of the Dahia Beel under Natore district, Bangladesh," Bangladesh Journal of Progressive Science and Technology, vol. 7(2), pp. 283-284, 2009.

[13] A. R. Joadder, "Socio-economic condition of fishermen of the "Mail Beel" under Mohanpur upazila of Rajshahi district in Bangladesh," Research Journal of Biological Sciences, vol. 3(10), pp. 1178-1181, 2008.

[14] H. Ali, M. A. K. Azad, M. Anisuzzaman, M. M. R. Chowdhury, M. E. Hoque, and M. I. Sharful, "Livelihood status of the fish farmers in some selected areas of Tarakanda upazila of Mymensingh district," Journal of Agroforestry and Environment, vol. 3(2), pp. 85-89, 2009.

[15] B. Paul, H. Faruque, and D. A. Ahsan, "Livelihood status of the fishermen of the Turag River, Bangladesh," Middle-East Journal of Scientific Research, vol. 18 (5), pp. 578-583, 2013.

[16] P. Halder, H. Ali, N. Gupta, M. S. B. Aziz, and M. S. Monir, "Livelihood status of fresh fish, dry fish and vegetable retails at Rajoir upazila of Madaripur district, Bangladesh," Bangladesh Research Publications Journal, vol. 5(3), pp. 262270, 2011. 
[17] B. M. S. Abdullah-Bin-Farid, S. Mondal, K. A. Satu, R. K. Adhikary, and D. Saha, "Management and socio-economic conditions of fishermen of the Baluhar Baor, Jhenidah, Bangladesh,” Journal of Fisheries, vol. 1(1), pp. 30- 36, 2013.

[18] N. G. Das, and M. Hossain, "Livelihood and resource assessment for aquaculture development in waterlogged paddy lands remote sensing, GIS and participatory approach, a joint research report by the GNAEP-GoB-DANIDA and Institute of Marine Sciences, University of Chittagong, Bangladesh," 2004, pp. 45-75.

[19] M. Hossian, "A preliminary survey on the fishermen and socio-economic status of fishermen of the Old Brahmaputra River, M.S. Thesis, Department of Fisheries Management, Bangladesh Agricultural University, Mymensingh,” 2007, pp. 95 .
[20] S. B. Bappa, M. M. M. Hossain, B. K. Dey, S. Akter, and M. Hasan-Uj-Jaman, "Socio-economic status of fishermen of the Marjat Baor at Kaligonj in Jhenidah district, Bangladesh," Journal of Fisheries, vol. 2(2), pp. 100-105, 2014.

[21] P. Pravakar, B. S. Sarker, M. Rahman, and M. B. Hossain, "Present status of fish farming and livelihood of fish farmers in Shahrasti upazila of Chandpur district, Bangladesh," American-Eurasia Journal of Agricultural and Environmental Sciences, vol. 13(3), pp. 391-397, 2013.

[22] M. Rahman, M. M. Rahman, M. M. Hasan, and M. R. Islam, "Livelihood status and the potential of alternative income generating activities of fisher's community of Nijhum Dwip under Hatiya upazila of Noakhali district in Bangladesh," Bangladesh Research Publications Journal, vol. 6(4), pp. 370379, 2012. 